\title{
An Anglo-Saxon fragment of Justinus's Epitome
}

\author{
J ULIA CR I C K
}

In 1910 , Samuel Brandt published a description and photograph of a fragment of Justinus's Epitome of the Historiae Pbilippicae of Pompeius Trogus. ${ }^{1}$ The leaf, whose present location is unknown, ${ }^{2}$ belonged at that time to the collection of Ernst Fischer at Weinheim. Fischer dated its script, an AngloSaxon minuscule, to about AD 800 , which, as Brandt observed, would mean that it antedated the earliest known manuscripts of the text, which are ninthcentury. ${ }^{3}$ Although E. A. Lowe indicated in his Codices Latini Antiquiores ${ }^{4}$ that the fragment was lost, it has continued to attract scholarly attention. Professor Bernhard Bischoff suggested that the fragment could be identified with a copy of Justinus listed among the books of Gerward, palace librarian of Louis the Pious. 5 This implied connection with the Carolingian court, taken together with Alcuin's naming of Justinus's work among the books described in the poem on York and his later association with the Carolingian court, ${ }^{6}$ has raised the possibility of an English origin for the Weinheim manuscript and therefore also for the earliest known branch of the text. As L.D. Reynolds remarked, 'This fragment has a significance quite out of keeping with its size.' 7

Recently, a single leaf written in Anglo-Saxon minuscule script was discovered in one of the volumes of miscellaneous fragments assembled by the eighteenth-century London book collector, John Bagford (see pl. VIII). A search through $C L A$ for comparable specimens of script revealed a striking

1 'Über ein Fragment einer Handschrift des Justinus aus der Sammlung E. Fischer in Weinheim', Neue Heidelberger Jabrbücher 16 (1910), 109-14.

2 Professor Helmut Gneuss has kindly confirmed this in a letter of 12 May 1986. Another lost fragment of potential relevance to my discussion is mentioned by W.M. Lindsay, Notae Latinae (Cambridge, 1915), p. 492; it too belonged to Fischer and was written in AngloSaxon script. 3 'Über ein Fragment', p. I 10.

4 The entry is marked with an obelus, signifying that the manuscript is untraced: E. A. Lowe, Codices Latini antiquiores, II vols. and suppl. (Oxford, 1934-71; and II, 2nd ed., 1972) (hereafter abbreviated $C L A$ ) Ix, no. 1370.

5 Lorsch im Spiegel seiner Handschriften (Munich, 1974), p. s6.

- As quoted by L.D. Reynolds in Texts and Transmission: A Survey of the Latin Classics, ed. L. D. Reynolds (Oxford, 1983 ), p. 197, n. 3. See also M. Lapidge, 'Surviving Booklists from Anglo-Saxon England', Learning and Literature in Anglo-Saxon England. Studies Presented to Peter Clemoes on the Occasion of his Sixty-fifth Birtbday, ed. M. Lapidge and H. Gneuss (Cambridge, 1985), pp. 39-89, at 46-7. 7 Texts and Transmission, ed. Reynolds, p. 197. 


\section{Julia Crick}

resemblance between the Bagford fragment (London, British Library, Harley \$91 5 , fol. 10) and Fischer's aforementioned leaf of Justinus. This resemblance made possible the identification of the text of the Harley fragment: it too comes from Justinus's Epitome, from bk xxIv.ii.6-10 and xxIv.iii.4-8. This section of text follows on fairly closely from that of the lost Weinheim leaf (bk xxIII.iii.3-7; xxIII.iv. I-xxIv.i.1). The Bagford fragment is written in lines of about $9.5 \mathrm{~cm}$, which accords with Brandt's description of the lost Weinheim fragment, whose lines were said to be 'etwa $9 \mathrm{~cm}$ lang'. ${ }^{8}$ Furthermore, the script of the Bagford fragment is identical with that of the Weinheim fragment. It would appear, therefore, that the two leaves are membra disiecta of a now dismembered manuscript. Since the Weinheim fragment has been lost, the discovery of the Bagford fragment provides a convenient opportunity for reassessment of their palaeography, provenance and text history.

THE PALAEOGRAPHY OF THE FRAGMENTS

The Bagford fragment is a thick, fuzzy Insular parchment which now measures $195 \times$ I $23 \mathrm{~mm}$. Only one column of text (eighteen lines) survives; but comparison with Fischer's broader leaf $(140 \times 170 \mathrm{~mm})$ shows that the manuscript must originally have been written in two columns. Brandt calculated from the extant text that each column had probably had twentyseven or twenty-eight lines, although only the upper twelve remained on the Weinheim leaf. Brandt also observed that Fischer's fragment had been cut down and then folded to make a cover for a thin quire (now lost), as can be seen from the holes caused by the binding. ${ }^{9}$ Fold-lines and small holes in the Bagford fragment indicate that it served a similar purpose.

The script of the two fragments is a handsome, practised Insular minuscule dating, in my opinion, from the middle of the eighth century - 'gewandte' and 'stattliche' in Brandt's words. Ascenders and minims have pronounced, diagonally wedged tops and tapering, pointed ends, as do descenders. The only signs of cursiveness are open $\mathbf{a}$ and certain ligatures: $\mathbf{c a} ; \mathbf{s t} ; \mathbf{i}$ after $\mathbf{f}, \mathbf{g}, \mathbf{t}$; and $\mathbf{e}$ after $\mathbf{c}, \mathbf{m}, \mathbf{r}, \mathbf{t}$ and $\mathbf{x}$. There is little abbreviation. Final -que and -bus are shortened with a simple medial comma. $\mathbf{d}$ always has the round-backed form, $\mathbf{p}$ is open-bowed and $\mathbf{g}$ has a well-defined looped bow rather than the narrow sinuous form associated with Northumbrian minuscule. $\mathbf{e}$ is closed but not quite theta-shaped and remains so even in ligature. The curve of $t$ when final in a word is turned down at the end. The ink of the Bagford leaf has the blackness typical of Insular production.

The palaeography of the Fischer-Bagford fragments requires further discussion. Various hypotheses about the origin of the Weinheim leaf have

8 Brandt, 'Über ein Fragment', p. rog.

9 'W'ie man aus den Löchern, die durch die Einheftung entstanden sind, ersieht' (ibid.). 


\section{An Anglo-Saxon fragment of Justinus's 'Epitome'}

been proposed but, as we know nothing of its early history, these are necessarily based on historical probabilities. This makes the interpretation of the physical appearance of the two fragments an important issue: Reynolds's remark that the Justinus tradition may have originated in England is one ultimately based on the script of the Weinheim fragment. The Anglo-Saxon minuscule in which the fragments are written is testimony to the fact that the text passed at some point through English hands. However, the question remains of whether the copying was done in England (and so represents one stage in an Insular textual tradition of the Epitome) or whether the fragments were written abroad in an Anglo-Saxon centre, using an exemplar uncovered by the book-collecting efforts of Anglo-Saxon missionaries. This in turn leads to further problems. How are books written in an Anglo-Saxon context abroad to be distinguished from those written in the British Isles? Moreover, how are books produced on the Continent by Anglo-Saxons to be distinguished from those written by continental scribes trained by Anglo-Saxons?

Scholarly opinion about the origin of the Weinheim fragment has been divided. Brandt favoured a continental origin. ${ }^{10} \mathrm{He}$ pointed to the impact of Insular script in certain continental centres, especially in what he called the Fuldische Scbreibprovinz, where Insular minuscule was written well into the ninth century. Brandt suggested Fulda as a possible place of origin not on the basis of script, but for complicated and, to my mind, insufficiently supported textual reasons which will be discussed below. Among more recent scholars, Lehmann has adopted Brandt's suggestion. ${ }^{11}$ However, the British Isles are currently accepted as the origin of the Weinheim leaf. ${ }^{12}$ As far as I know, the justice of these rival claims has not been argued in palaeographical terms.

Work on the complex palaeography of the Anglo-Saxon mission has concentrated on studies of particular continental centres such as Würzburg, Mainz and Fulda, rather than on the more general aspects of the development of Anglo-Saxon script on the Continent. ${ }^{13}$ The many entries in Lowe's CL.A

10 Ibid. p. 112.

1 Lehmann refers to the Weinheim leaf as 'ein Bruchstück einer in fuldischer Insulare geschriebenen Handschrift', Erforschung des Mittelalters, s vols. (Stuttgart, 1959-62) 111, I61.

12 Professor Gneuss, in a letter of 12 May 1986, informs me that 'among all the leading authorities' its Insular origin 'does not seem in doubt now'.

13 For a guide to the various centres and for references to facsimiles see B. Bischoff, Mittelalterlicbe Studien, 3 vols. (Stuttgart, 1966-81) 111, 5-38. See also his Paläograpbie des römiscben Altertums und des abendländiscben Mittelalters (Berlin, 1979), Pp. 119-22, and Lowe, $C L A$ vili, p. vi. For individual centres see B. Bischoff and J. Hofmann, Libri S. Kyliani: Die Würzburger Scbreibschule und die Dombibliotbek im VIII. und IX. Jabrbundert (Würzburg, 1952); W.M. Lindsay and P. Lehmann, 'The (Early) Mayence Scriptorium', Palaeographia Latina 4 (1925), 19-39; H. Spilling, 'Angelsächsische Schrift in Fulda', Von der Klosterbibliotbek zur Landesbibliotbek, ed. A. Brall (Stuttgart, 1978), pp. 47-98; H. Köllner, Die illuminierten Handschriften der Hessiscben Landesbibliotbek Fulda 1 (Stuttgart, 1976); 


\section{Julia Crick}

labelled as possibly 'continental' or 'Insular' in origin show that there is considerable difficulty in localization. ${ }^{14}$ The output of the first generation of Anglo-Saxon missionaries would probably betray no hint of having been written anywhere other than England, except possibly if the membrane were prepared according to continental rather than Insular practice. Würzburg, Universitätsbibliothek, M. p. th. f. ${ }^{1499^{15}}$ (dated by Lowe to the second half of the eighth century) is one example of a manuscript whose materials are continental but whose script is English. Many schools in Anglo-Saxon missionary centres were new foundations without a previous tradition of script. Writing masters, therefore, would probably be dealing with the unlettered, not introducing a foreign element into a previously assimilated skill. Herrad Spilling has pointed out that it was training rather than exemplars which shaped script - those scribes associated with Anglo-Saxon schools abroad could be faced with exemplars from Mercian, Northumbrian and Celtic scriptoria as well as examples of Frankish, Italian and Spanish hands but they kept to the style which they had been taught, the Southumbrian in the case of Fulda (and, presumably, Northumbrian at Echternach and Werden). ${ }^{16}$ As she has noted, continental Anglo-Saxon script was not isolated from developments in England. ${ }^{17}$ Two manuscripts of the later eighth century, one from Northumbria and one from Werden, a house connected with Echternach and therefore having Northumbrian associations, are written in a strikingly similar set minuscule-delicate and attenuated. ${ }^{18}$ On several counts, then, it is possible that an eighth-century manuscript written on the continent, especially one lacking decoration (inasmuch as this provided another medium for local variation), may be indistinguishable from Insular work.

However, many examples of Anglo-Saxon script written on the continent are distinctive, whether as a result of the influence of local writing masters or

G.1. Lieftinck, 'Le ms. d'Aulu-Gelle à Leeuwarden exécuté à Fulda en 836 ', Bullettino dell' 'Archivio paleografico italiano' and ser. I (1955), 1 1-17; R. Drögereit, Werden und der Heliand (Essen, 1950). Also on this subject see H. Spilling, 'Irische Handschriftenüberlieferung in Fulda, Mainz und Würzburg', Die Iren und Europa im früberen Mittelalter, ed. H. Löwe, 2 vols. (Stuttgart, 198z) II, 876-902; J. Autenrieth, 'Insulare Spuren in Handschriften aus dem Bodenseegebiet bis zur Mitte des 9. Jahrhunderts', in Paläographie 1981 , ed. G. Silagi (Munich, 198 2), pp. I45-57; and G. Baesecke, Der Vocabularius Sti Galli in der angelsäcbsischen Mission (Halle, 1933 ), but note that Baesecke's comparisons with English material apparently datable to the eighth century require reassessment, since many of the charters which he cites would now be considered copies or forgeries of the ninth and even early tenth centuries (e.g. $S_{5} 6, S_{59}, S_{264}$ and $S_{1188}$.

14 See also D.O Cróinín's alternative hypothesis in 'Rath Melsigi, Willibrord, and the Earliest Echternach Manuscripts', Peritia 3 (1984), 17-42. ${ }^{15} C L A$ Ix, no. 1427.

16 'Angelsächsische Schrift', p. S1. ${ }_{17}$ Ibid. pp. 94-5.

$18 C L A \mathrm{~S}$, nos. 1703 and 168 \%. This view has been opposed controversially by Ó Cróinin, who regards Rath Melsigi as 'the scriptorium in which the first-generation Echternach scribes received their formation' ('Rath Melsigi', p. 42). 


\section{An Anglo-Saxon fragment of Justinus's 'Epitome'}

merely of lack of familiarity with the aspect of Insular script. The work of the scribe named Willibaldus demonstrates continental influence. ${ }^{19} \mathrm{His}$ hand has features typical of continental Insular minuscule - the long descenders, uprightness and lack of energy described by Bischoff as typical of this script c. $800 .{ }^{20}$ Spilling has charted the various types of minuscule at Fulda from the narrow and attenuated initially script to the broader style which had evolved by the early ninth century, but her conclusions agree with Bischoff's more general remarks: 'Als charakteristisch für Fuldas Schrift hatten sich aufrechte Haltung, Regelmässigkeit und bewusste Ordnung erwiesen, so wie als Kehrseite der strengen Disziplin ein gewisser Mangel an Dynamik'. ${ }^{21}$ Other features noted as distinctive of the continental form of Insular script are clubbed ascenders, open $\mathbf{a}$, theta-shaped $\mathbf{e}$, a long and angular flat-topped $\mathbf{g}$ (often shaped like a flat-topped figure 3 ), a form of $q$ in which the bowl is open and angled, and a downward tick at the right-hand end of the lower stroke of t. 22

When the script of the Bagford fragment is measured against these criteria and compared with examples of the scripts evolved at the various continental centres it is clear that, in aspect at least, it does not fit the continental pattern. Although it has clarity and uprightness, it lacks the long descenders and imitative aspect of continental examples. Moreover, it uses a pure Insular canon of letter forms. There are no majuscule letters or unusual forms, in contrast with the examples of continental Insular script (admittedly of a higher grade) from Reichenau, Murbach, Fulda, Sankt Emmeram and Würzburg, which Baesecke compared with the Vocabularius of Sankt Gallen. ${ }^{23}$ The script of the Fischer-Bagford leaves does not include the distinctively contintental forms of $\mathbf{g}$ and $\mathbf{q}$ mentioned above, although the $\mathbf{a}$ and $\mathbf{t}$ fit the pattern described and the $e$ is almost theta-shaped. The absence of some of the symptoms would not preclude the identification of a piece of script as continental, but our fragment has balanced proportions without the stiff, regimented aspect of certain continental examples, and it also possesses the vitality which those examples lack.

I should suggest that the features which it shares with continental forms of Insular script are easily accounted for: it is the kind of minuscule - set with a few cursive features - which must have served as the model for scribes working in Insular centres abroad. Certain manuscripts of this type are known

19 For example CLA S, no. **1400: Oxford, Bodleian Library, Laud misc. 263 (S.C. 1000).

20 'Kurz vor und um 800 ist die Schrift meist gerade, mit langen Unterlängen, oft etwas schwunglos' (Paläograpbie, p. I 2 I). 21 Spilling, 'Angelsächsische Schrift', p. 93.

22 These additional criteria were suggested to me by Dr M. Lapidge.

23 Der Vocabularius, esp. pp. 18-23. It should be noted that Baesecke was comparing half-uncial and not minuscule scripts. 


\section{Julia Crick}

to have been used on the continent. London, British Library, Egerton 2831 , fols. I $10-43^{24}$ was written at Tours partly in Insular, partly in Caroline minuscule. Something not unlike this example was apparently followed by the scribe of Vatican City, Biblioteca Apostolica Vaticana, Pal. lat. 259;25 compare the writing of dicitur. ${ }^{26}$ The 'Moore Bede', Cambridge, University Library, Kk. 5. 16, ${ }^{27}$ written in a rounded set-cursive minuscule, was another such exemplar: it contains additions in North French Caroline minuscule and is known to have belonged to the palace library of Charlemagne. ${ }^{28}$ The type of script represented by the Justinus fragments would seem to lie behind certain continental examples of Insular script. New York, Pierpont Morgan Library, William S. Glazier Collection, G. $26^{29}$ is a continental production perhaps imitating some such original. Another closer continental counterpart of the script of the Fischer-Bagford leaves is provided by the canonical collection from Werden. 30

The antecedents of the script of the Fischer-Bagford leaves are not obvious. Lowe suggested a Northumbrian origin and a date in the mid-eighth century on the basis of comparison with Scribe D of the 'Leningrad Bede', Leningrad, Public Library, Q. v. I. $18 .{ }^{31}$ This is a convincing parallel and, being a localized and datable specimen, provides a useful fixed point for comparison. Hand D of the 'Leningrad Bede' in particular is close to our fragment in proportions, the use of open a and the form of the e ligature (a closed loop). The other hands of this manuscript share certain other features with the Fischer-Bagford fragments. ${ }^{32}$ Hand $\mathrm{A}$ has the ligature of $\mathbf{c}$ with $\mathbf{a}$ and high $\mathbf{c}$ before $\boldsymbol{o}$, as well as the occasional occurrence of ticked-down $t$ and the standard use of round-backed $\mathbf{d}$. The same form of $\mathbf{t}$ occurs sometimes in Hand $\mathrm{C}$ as does the co combination. Forms of $\mathbf{g}$ vary from the sinuous variety usually associated with Northumbrian script to the rounded form found in the Fischer-Bagford leaves. Lowe suggested that Hand D represents an earlier tradition than the attenuated script of the other scribes. Brown's view of the development of eighth-century minuscule concurs with this observation, the script of the earlier part of his Phase II up to and including the 'Moore Bede'

24 CLA 11, no. *196b. 25 CLA 1, no. 90.

26 $C L .111$, no. * 1966 , col. $\mathrm{B}$, line 7; $C L A$ I, no. 90, line 7 .

2- CLA1I, no. I 39; ed. in facsimile by P. Hunter Blair (with a contribution by R.A. B. Mynors), The Moore Bede: an Eightb-century Manuscript of the Venerable Bede's Historia Ecclesiastica Gentis Anglorum in Cambridge University Library (Kk.).16), EEMF 9 (Copenhagen, 1959).

28 B. Bischoff, 'Die Hofbibliothek Karls des Grossen', Mittelalterlicbe Studien III, $149-69$.

29 CLA xi, no. ** ${ }^{*} 339.30$ Werden und der Heliand, pl. 6 and pp. 25-6.

31 CLA Ni, no. 1621 .

32 On this manuscript see M. B. Parkes, The Scriptorium of Wearmoutb-Jarrow, Jarrow Lecture 1982 (Jarrow, 1983). For facsimiles see Parkes, ibid. pls. 1 and 3, and E. A. Lowe, Palaeograpbical Papers 1907-1965, ed. L. Bieler, 2 vols. (Oxford, 1972) 11, pls. 95-6. 


\section{An Anglo-Saxon fragment of Justinus's 'Epitome'}

having broader letters and shorter ascenders and descenders than the later elongated script of which the 'Leningrad Bede' provides the earliest example. ${ }^{33}$ Lowe also suggested that the scribe of Hand $D$ was not trained at Jarrow as the others had been. ${ }^{34}$ Parkes has rejected this view, arguing that the differences between Hand $D$ and the other hands are explicable within the development of minuscule at Wearmouth-Jarrow. ${ }^{35}$ This argument does not, however, detract from Lowe's concluding remarks that Hand D's 'type of Anglo-Saxon minuscule is not very distinctive, yet it is not easy to find a close parallel to it'. ${ }^{36}$ The script of the Weinheim leaf was the nearest which he could adduce.

The differences in appearance between Hand D and Hands A, B, and C were sufficient to lead Lowe to the conclusion that Hand D was the product of a different scribal training from the others. However, the script of the first three hands, all from Wearmouth-Jarrow, is by no means homogeneous. The variety of letter-forms and scribal practice evident within one manuscript, a regularly written example at that, warns against over-optimistically establishing and applying criteria for localization. From the consideration of general types of script rather than isolated letter forms, a few other comparisons suggest themselves. Two examples in the Southumbrian tradition show some degree of similarity with our fragment. London, BL Royal 4. A. xIv, fols. $107-8,{ }^{37}$ a bifolium to which Lowe ascribed a Southern English origin, ${ }^{38}$ is written in a similar type of script but it is less controlled and upright and its letter-forms do not offer many parallels. A manuscript from Fulda, a centre in the Bonifatian (Southumbrian) tradition, now Kassel, Landesbibliothek, Theol. fol. $21,{ }^{39}$ is comparable in proportions and in the use of open a, but the overall impression does not suggest close agreement. Manuscripts directly or indirectly associated with Northumbria offer closer parallels. Apart from the 'Leningrad Bede' and the canonical collection (already mentioned as an heir to this type of script) which comes from Werden, a house founded in the Willibrordian (Northumbrian) tradition, ${ }^{40}$ there is an Echternach book which contains a comparable hand, seen in the second of the two grades in Lowe's plate of Paris, Bibliothèque Nationale, lat. 9527.41

In my opinion, Lowe's comparison of the Weinheim fragment with

33 T. J. Brown, 'The Irish Element in the Insular System of Scripts to circa A.D. 890 ', in Die Iren und Europa, ed. Löwe, 1, 101-19, at ins. ${ }^{34}$ Palaeographical Papers, ed. Bieler, I, 448.

35 The Scriptorium, p. 7. 36 Palaeographical Papers, ed. Bieler, II, $44^{-1} 9$ at 449.

${ }^{37}$ CLA II, no. *216.

38 The bifolium now serves as fyleaves for a late tenth-century manuscript which Lowe (in $C L A$, ibid.) describes as 'palaeographically related' to London, BL, Royal 2. B. v.

$39 C L A$ virl, no. II 34.40 See above, n. 30.

${ }^{41} C L A \mathrm{v}$, no. ; 4 . A rguments for the Irish origin of a binding fragment from an Echternach volume, now fol. 201 of this manuscript, are put forward by O Cróinín, 'Rath Melsigi', pp. 26-8. 


\section{Julia Crick}

Hand D of the 'Leningrad Bede' provides the closest parallel. The grade, uprightness and ordered aspect of the hand of our fragment are most comparable with extant examples from Northumbria rather than those from Southumbria. The script of the Fischer-Bagford fragments seems to fall between the very formal hybrid minuscule and the rather splayed, rapid cursive associated with Southumbria. The 'Leningrad Bede' is also a dating yardstick. Fischer had suggested a date of $c .800$ for his fragment, a suggestion supported by Franz Steffens on the basis of comparison 'with the eighthcentury volume of Bede's Historia ecclesiastica in the British Museum'.42 Steffens did not give the shelfmark of the manuscript which he had in mind, but two manuscripts fit his description: Cotton Tiberius A. xiv and Cotton Tiberius C. ii. ${ }^{43} \mathrm{It}$ is probable that he meant Tiberius C. ii, dated to the end of the eighth century by Lowe, rather than Tiberius A. xiv (placed in the midcentury). However, neither provides a convincing parallel for the script of the Weinheim fragment by comparison with others which CLA can now offer.

To judge from script and membrane, then, the Bagford fragment would seem to be of Insular origin but, as we have seen, this does not exclude absolutely the possibility that it was written on the continent.

THE PROVENANCE OF THE FRAGMENTS

Since both fragments were used in bindings, it must be assumed that the original manuscript was broken up some time before they became the object of collectors' attentions. John Bagford's collecting was done at the beginning of the eighteenth century (he died in 1716 ). It is not difficult to see how the leaf came into his possession. He accumulated a considerable collection of manuscript fragments taken from book bindings ${ }^{44}$ and he supplied such material to others..$^{45} \mathrm{He}$ was associated with Humfrey Wanley, Hans Sloane, and other important bibliophiles including Robert Harley, whom he served ' in the way of out-of-course books'. ${ }^{46} \mathrm{He}$ travelled abroad in search of interesting specimens: in 1707 he described in a letter to Hans Sloane a fragment which he had seen at auction in Amsterdam and which he thought to have belonged to a volume 'at Bennet College at Cambridge', that is, Corpus Christi. ${ }^{47}$ Although no details are known about the compilation of Harley 5915 , the associations of a leaf of Ælfric's Grammar contained in the same volume show how such fragments could travel. This leaf has been identified as belonging to the same

42 'dem 8. Jahrhundert angehörenden Codex von Bedas Kirchengeschichte im Britischen Museum'. ${ }^{43} C L A \mathrm{~S}$, no. 1703; CL $A$ II, no. 191.

4 M. McC. Gatch, 'John Bagford as a Collector and Disseminator of Manuscript Fragments', The Library, Gth Ser. 7 (1985), 95-1 14, at 96.45 Ibid. p. rog.

${ }^{46}$ Quoted by C. E. Wright, Fontes Harleiani: $A$ Study of the Sources of the Harleian Collection of Manuscripts preserved in the British Museum (London, 1972), p. 59.

47 London, BL Sloane 4040, $347 \mathrm{r}$. 


\section{An Anglo-Saxon fragment of Justinus's 'Epitome'}

manuscript as another fragment of that work (then at Sigmaringen and now in Bloomington, Indiana) which had come from a book binding and had been acquired in Düsseldorf. 48

The history of Fischer's fragment of Justinus was described by Brandt. ${ }^{49}$ Fischer had obtained it through the Antiquariat Carlebach in Heidelberg from the estate of Fridegar Mone. He had probably received it from his father, Franz Joseph Mone, a professional historian and an enthusiastic collector of manuscripts and charters. Apart from the years 1827 to 1831 when he was professor at the University of Leuven, the elder Mone had spent his working life in Heidelberg as professor and head librarian before becoming Archivdirektor. He published on a wide range of subjects, but his major work was philological. He died in 1871 . Brandt's account of the fragment's history was tentatively extended by E. A. Lowe who added that the fragment may have fallen into the hands of a Dr Amt of Quedlinburg after the dispersal of Fischer's collection. Lowe did not state his source. Dr Amt is known as the owner of another English fragment which reappeared after his death in Berlin in about $1934 .{ }^{50}$

Fulda was proposed by Brandt as a candidate for the fragment's early provenance, being a sizeable library not too far from the Heidelberg area where Mone was based for much of his life. Two copies of Justinus were recorded in the sixteenth-century catalogue of books at Fulda. ${ }^{51}$ Franciscus Modius, who used these for his I 587 Frankfurt edition of Justinus, had noted that one manuscript was 'longobardica littera scriptus', his stock description of pre-Caroline minuscule of all kinds, according to Brandt. ${ }^{52}$ Lehmann had identified extensive quotations from Justinus in the commentary on Macchabees by Hrabanus Maurus which suggested the presence of the work in Fulda's library in the ninth century. ${ }^{53}$ Brandt took this as confirmation of the antiquity of Modius's volume in 'Lombardic script'. Thus Brandt equated with Modius's manuscript the book to which the Weinheim fragment had once belonged. Unfortunately, as Brandt acknowledged, the edition of is 87 does not record readings found in the fragment. A solution was supplied by Franz Rühl who carried out fundamental work on the text of Justinus, and concluded that Modius had produced his edition hurriedly and carelessly, paying scant attention to his manuscripts. ${ }^{54}$ Despite this, Brandt's hypothesis

48 R. L. Collins, 'Two Fragments of Elfric's Grammar: The Kinship of Ker 384 and Ker 242', Annuale Mediaevale s (1964), s-12. 49 'Über ein Fragment', p. 111.

so P. Sims-Williams, 'Milred of Worcester's Collection of Latin Epigrams and its Continental Counterparts', $A S E$ 10 (1982), 21-38, at 29, n. 27.

s1 Die Bibliothek des Klosters Fulda im 16. Jabrhundert: die Handschriften-Verzeichnisse, ed. K. Christ (Leipzig, 1933), p. 268.52 'Über ein Fragment', p. $112-14.53$ Ibid. p. II $_{3}$.

54 'Modius, der auf seine Justinausgabe nur wenig Zeit und Fleiss verwandt hat, führt unglücklicherweise seine Handschriften nur sehr selten an' ('Die Textesquellen des Justinus', Jabrbücher für classische Pbilologie, Suppl. Band 6 (Leipzig 1872-3), 1-160, at 87-8). 


\section{Julia Crick}

has little to recommend it, for the Epitome is known to have been in other Carolingian libraries in the ninth century. ${ }^{55}$ The claim for a Fulda provenance seems to have been set aside in recent scholarship in favour of an attractive alternative suggested by Bernhard Bischoff.

A booklist dating from the mid-ninth century (found in Vatican City, Biblioteca Apostolica Vaticana, Pal. lat. 1877) records the following among the books bequeathed by one Geruuardus 'in Gannetias' to the monastery of Lorsch: ' ' I . Compotum, liber Horosii et Ioannis episcopi Constantinopolitanae et Augustini de quantitate temporis et de praedestinatione aduersus Caelestium et Pompei historiarum libri xliiii in uolumine i'.56 Lehmann identified Geruuardus as Gerward, a benefactor of Lorsch, and Gannetia as Gent near Nymwegen, Gelderland (Netherlands). He also observed that the listing of a Justinus among Gerward's books constituted the earliest reference to the work in a continental library (regarding all the manuscripts of the work as ninth-century or later). He concluded that Gerward's copy may have been the ancestor of the German and French textual tradition of Justinus, one which probably has its roots in York. ${ }^{57}$ It was Bischoff who pointed to the Weinheim fragment as a manuscript of suitable date to be the candidate for Gerward's book. ${ }^{58}$

Heinz Löwe's work on Gerward has established that the Gerward of the book-list could be equated with the court librarian of that name who served Louis the Pious. ${ }^{59} \mathrm{He}$ is first found as 'clericus' bequeathing land in Gannita to Lorsch in 814 . Lowe identified him as 'Gerowardus filius Landwardi', who gave estates in Gelderland to the see of Utrecht in 828. Einhard records that he was court librarian in the same year. ${ }^{60}$ Löwe envisaged Gerwardus seeking an education at Lorsch while in minor orders, before going to the imperial court to continue it and to embark on a career. He was a correspondent of Einhard and was apparently sent a copy of the Vita Karoli. Bischoff juxtaposed the close links of Adalung (then abbot of Lorsch) with the court school and Gerward's promotion at court. ${ }^{61}$ Gerward may have retired from court after the death of Louis in 840 and he perhaps returned to Gannita to adminster Lorsch's estates there. Löwe also ascribed to Gerward the composition of the first part of the Annales Xantenses. This attribution was suggested by the combination of the

55 Texts and Transmission, ed. Reynolds, p. 198.

56 P. Lehmann, 'Das älteste Bücherverzeichnis der Niederlände', Het Boek I 2 (1923), $207^{-1} 3$.

57 'Sollten wir da den Stammvater der vermutlich im englischen York würzelnden deutschen und französischen Justinüberlieferung haben?' (ibid. p. 213 ). ${ }^{58}$ Lorsch, p. 56.

59 'Studien zu den Annales Xantenses', DAEM 8 (1951), s8-99, at 88. Löwe quotes Einhard's report of a miracle which befell 'Gerwardus palatii bibliothecarius' on his return from Nymwegen to the court at Aachen. See below, n. 60 .

60 Translatio Santtorum Marcellini et Petri auctore Einbardo, ed. O. Holder-Egger, MGH, SS is (Hannover, 1887), 239-64, at 258.

${ }^{61}$ Lorsch, Pp. 33-4. 


\section{An Anglo-Saxon fragment of Justinus's 'Epitome'}

author's knowledge of Frisia and the court, by certain periods of sparseness in the narrative of activity in the Netherlands (suggesting the author's absence), and by the unexpected detail about places neighbouring Lorsch's estates. ${ }^{62}$

This synopsis of Gerward's career provides a plausible context for his acquisition of a book written by an Anglo-Saxon or a rare text. There is direct evidence that Gerward was not far removed from Anglo-Saxon activity. Lehmann identified in one of Gerward's volumes, a book in uncial script datable to $c .700$ (now Vatican City, Biblioteca Apostolica Vaticana, Pal. lat. $210), 63$ a list, written in Insular half-uncial of the early eighth century, of the books of an Anglo-Saxon missionary active in the Netherlands. The works named were of practical value for the missionary field - gospel books, patristic texts, hagiography and liturgical material. Less immediately functional books were also in the possession of Anglo-Saxon missionaries, however. Hofmann has studied the volumes whose association with Anglo-Saxon missionaries on the continent is shown by glosses in Old English and Old High German. ${ }^{64}$ Most of the volumes have a theological or pastoral function. However, they include a copy of the De bello Iudaico of Hegesippus, a sixth-century book written in Italian half-uncial (Kassel, Landesbibliothek, Theol. fol. 65). ${ }^{65} \mathrm{In}$ a Würzburg booklist of perhaps the later eighth century, there is a 'Liber Orosii' among the copies of sermons and standard religious works. ${ }^{66}$ The Hegesippus and Orosius are both associated with the Bonifatian mission but there are examples too from the missionary field established by the Northumbrian Willibrord in the Netherlands, near Gerward's sphere of activity. A copy of Livy bears the ex-libris of one Theatbertus, bishop of Dorestad. As a bishopric at Dorestad is otherwise unknown, this inscription has stimulated some controversy. Certain scholars have favoured the identification of this bishop with 'Thiaterd', who became bishop of nearby Utrecht in 784 . Whether the book belonged to Thiaterd of Utrecht or to an otherwise unknown bishop of Dorestad (whom Levison would place in the early eighth century) is not important in this context. Either way, the inscription shows that an old copy of a classical history was in the hands of a bishop working in the area of Utrecht in the eighth century. ${ }^{67}$ Thus Bischoff's theory is credible in terms of the general

62 Löwe, 'Studien', pp. 91-8. ${ }^{63} C L A$ 1, no. 84.

$64 \mathrm{~J}$. Hofmann, 'Altenglische und althochdeutsche Glossen aus Würzburg und dem weiteren Missionsgebiet', BGDSL 85 (1963), 27-131.

65 CLA viII, no. I I 39. Hofmann, 'Altenglische und althochdeutsche Glossen', pp. 50-2. On this manuscript see M.B. Parkes, 'The Handwriting of St Boniface: a Reassessment of the Problems', BGDSL 98 (1976), 161-79.

66 Lowe, Palaeographical Papers, ed. Bieler, 1, 239-50.

67 For Levison's view, see 'Bischof Theutbert von Wijk bij Duurstede', Neues Archiv der Gesellschaft für ältere deutsche Geschichtskunde 33 (1907-8), $917^{-29}$, and England and the Continent in the Eightb Century (Oxford, 1946), Pp. 62 and 82 . One alternative was supported by 


\section{Julia Crick}

historical background: Anglo-Saxons were actively seeking out old books and their missionary field was close to Gerward's estates.

Despite this, Gerward's connection with our manuscript remains quite unsubstantiated. But if we were to hypothesize an alternative history of the Fischer-Bagford copy of Justinus, I suggest that we should be looking in the same sphere of book collecting. Hofmann's study has shown the number of old manuscripts (some dating back to the fifth century) being used by the Anglo-Saxon missionaries.

This activity, of course, was only part of a well charted tradition established over the preceding century. Bede describes how Benedict Biscop brought back to Britain many books 'omnis diuinae eruditionis', which he had assembled at Vienne on his third trip to Rome. ${ }^{68}$ On a later visit, he acquired more books with a wider range of subject matter: 'innumerabilem librorum omnis generis copiam adportauit' ${ }^{69}$ These books, together with other treasures brought back from Rome (relics, pictures, a letter of privilege from the pope, an ordo of psalm-singing), were used in the foundation of Jarrow. ${ }^{70}$ Bede's erudition provides the concrete proof of the breadth of what he describes as this 'most extensive and distinguished library'. ${ }^{71}$ Laistner's work on Bede's sources, although requiring some modification in the light of subsequent scholarship, provides an indication of its scope. ${ }^{72}$

Several potential sources of intellectual contact may have been drawn on during the development of the library at York described by Alcuin. This poetic account provides our sole reference to the presence of Justinus's Epitome in England: no quotation from it has as yet been identified in the work of any Anglo-Saxon author. ${ }^{73}$ Whether the appearance here of 'Pompeius' with 'Plinius' among the 'historici ueteres' was for purposes of alliteration rather than as a statement of fact is debatable. Pliny's Historia naturalis was certainly

Lehmann, 'Das älteste Bücherverzeichnis', p. 2 ro: 'Thiaterd in dem jungen Bischofskatalog des 14. Jahrhunderts ist wohl eine späte Entstellung von Thiatbert, Theutbert'. See also W. Wattenbach and W. Levison, Deutschlands Geschichtsquellen im Mittelalter. Vorzeit und Karolinger, s vols. (Weimar, 1953-73) 1, 173-4. For a plate of the inscription see Analecta Liviana, ed. T. Mommsen and G. Studemund (Leipzig, 1873), pl. 4. On Theutbert's manuscript see also T. J. Brown, 'An Historical Introduction to the Use of Classical Latin Authors in the British Isles from the Fifth to the Eleventh Century', SettSpol 22 (1975), 23793, at 279.

68 Historia abbatum, $\S_{4}$ (Venerabilis Baedae opera bistorica, ed. C. Plummer, 2 vols. (Oxford, 1896 ) I, 364-87, at 367). ${ }^{69} \mathrm{lbid}$. $\$ 6$ (ed. Plummer, p. 369).

$70 \mathrm{Cf}$. also the similar collection of Cuthwine, bishop of the East Angles: D. Whitelock, 'The pre-Viking Age Church in East Anglia', ASE I (1972), I-22, at 9.

71 'Bibliothecam . . . nobilissimam copiosissimamque': Historia abbatum, §1 1 (ed. Plummer, p. 375).

72 M. L. W. Laistner, 'The Library of the Venerable Bede', in Bede: bis Life, Times and Writings, ed. A.H. Thompson (Oxford, 1935), pp. 237-66.

73 Brown, 'An Historical Introduction', pp. 276 and 286. 


\section{An Anglo-Saxon fragment of Justinus's 'Epitome'}

known in England then. ${ }^{74}$ The probable founder of the library, Archbishop Ecgberht of York, was a correspondent of Bede. Several of Ecgberht's predecessors in the see corresponded with Archbishop Theodore, under whom a school was established at Canterbury. Some had been associated with Whitby, a house known for intellectual activity. Among them was Wilfrid, whose journeys abroad are well known. Another future bishop, though not of York, who had received training at Whitby was a traveller and collector of books and other treasure from the continent. ${ }^{75}$

The process of the acquisition and transmission of texts came full circle in the later missionary activity of the Anglo-Saxons. Boniface's letters requesting copies of books needed by the missionaries show that scriptoria in the British Isles played an important part in the re-export of texts to the continent. ${ }^{76}$ The original exemplars themselves sometimes returned to the continent. A fifthcentury uncial copy of Jerome's Commentarius in Ecclesiasten (Würzburg, Universitätsbibliothek, M. p. th. q. 2) ${ }^{77}$ is one such case and it provides a graphic illustration of the process of acquisition described above. That the book was brought early to England is indicated by the ex-libris of a certain abbess Cuthsuuith, who has been identified as the head of a house in the Worcester area $c .700 .{ }^{78} \mathrm{It}$ was at this time that a few leaves of the book were replaced in English uncial script. ${ }^{79}$ The addition of annotations in the hand of a glossator of the Ragyndrudis codex (Isidore's Synonyma) ${ }^{80}$ indicates that the book must have been on the continent by the early ninth century when that glossator was active. ${ }^{81}$ Würzburg therefore has been suggested as a possible provenance.

The career of Liudger shows how missionary work linked up a network between Rome, England and the continental Missionsgebiet for the transmission of books. Liudger was a Frisian noble associated with Willibrord's circle who later founded Werden, a house itself not far from Frisia. He had spent in total more than four years studying under Alcuin at York, having been sent there from Frisia in order to be ordained as a deacon by Archbishop Ælberht. Liudger had later made a pilgrimage to Rome and visited Montecassino. Drögereit has suggested that, when Werden was founded, books which

${ }^{4} C L A$ x, no. Is 78a. Cf. Texts and Transmission, ed. Reynolds, p. 309. See also Brown, 'An Historical Introduction', p. 275; Alcuin: The Bishops, Kings, and Saints of York, ed. P. Godman (Oxford 1982), p. 125 , n. to line is49.

75 See Bede, Historia ecclesiastica, iv.23. This is Bishop Oftfor whom Sims-Williams associates with the travels of an uncial codex: see below, $n .78$.

76 Cf. Parkes's remarks, The Scriptorium, p. 19. $77 C L A$ ix, no. 1430 a.

78 See P. Sims-Williams, 'Cuthswith, seventh-century Abbess of Inkberrow, near Worcester, and the Würzburg Manuscript of Jerome on Ecclesiastes', ASE S (1976), 1-2 I, especially 13-21. ${ }^{79} C L A$ ix, no. 1430b. 80 CL $A$ vili, no. 1197.

81 Hofmann, 'Altenglische und althochdeutsche Glossen', p. 47. 


\section{Julia Crick}

Liudger had once owned in York were brought to stock the new library. 82 Although Bischoff has qualified Drögereit's identification of books from York among manuscripts known to have belonged to Werden, drawing attention to the date of their script (little before $c .800$ ), ${ }^{83}$ Liudger himself must have had a share in the introduction of the volumes in Insular script which the library contained. There are no Anglo-Saxons associated with Werden to whom these imports could be attributed.

\section{THE TEXT HISTORY OF THE FRAGMENTS}

The only grounds for identifying the Fischer-Bagford fragments with the manuscript used at the Carolingian court and probably introduced there by Gerward would be textual. Unfortunately, there is so little of the Justinus fragments that full collation with Rühl's textual analysis is not possible. ${ }^{84}$ Brandt fitted the Weinheim fragment into the so-called 'transalpine group' of manuscripts, which offers the best and oldest text, ${ }^{85}$ basing his argument on the characteristic reading 'adtraxerat' for 'adstruxerat'. ${ }^{86}$ Most readings in the Bagford fragment, when compared with the apparatus of Otto Seel's recent edition, ${ }^{87}$ corroborate Brandt's observation that this is indeed a transalpine text. However, the Bagford fragment contains minor variants, not recorded by Seel and which therefore would appear to be preserved only in this manuscript (see Appendix, below). On the recto of the fragment, in xxiv.ii.9, where Seel's text reads 'neque in contumeliam eius se aliam uxorem aliosue quam filios eius liberos habiturum', there is 'neque ... uxorem aliose qua ' $m$ ' filios eius liberum habiturum'. An $e t$ is added after Arsinoe in the following sentence. The verso of the fragment has other such variants: xxiv.iii.s utique (for ubique), xxIv.iii.6 celebrandam (for celandam), and xxiv.iii.8, although it is now unclear because of a stain, contraxissent (for contraxisset). Comparison of Brandt's plate of the Weinheim fragment with Seel's edition reveals idiosyncratic readings in the Weinheim leaf as well. At xxiIr.iii.s the Weinheim fragment reads uenire for wenere (Seel does not record any variants here). At the end of bk xxiII.iii (sentence 12 ) the usual 'adiecit' is replaced by 'abiecit', a reading recorded by Seel in one other manuscript, which belongs to the $\gamma$ class (Florence, Biblioteca Laurenziana, 66. 21). The Florence manuscript had given Rühl cause for alarm on account of its independence from all other manuscripts of the work but its oddities were dismissed by Seel as erroneous and capricious readings. ${ }^{88}$ The

82 On Liudger see Drögereit, Werden und der Heliand, pp. 66-82, especially 66-71.

83. In his review of Werden und der Heliand in Anzeiger für deutscbes Altertum 66 (195 2-3), 7- 2.

8+ 'Die Textesquellen des Justinus'. 85 Texts and Transmission, ed. Reynolds, p. 197.

86 'Über ein Fragment', pp. $113-14$.

87 M. Iuniani Iustini epitoma bistoriarum Pbilippicarum Pompei Trogi (Stuttgart, 1972).

88 Ibid. pp. vii-viii. 


\section{An Anglo-Saxon fragment of Justinus's 'Epitome'}

presence in the Fischer-Bagford fragments of readings not found in other manuscripts of the transalpine group indicates that our manuscript cannot stand at the head of the textual tradition in the way that Bischoff has tentatively suggested.

\section{CONCLUSIONS}

It has been presumed that, as Gerward was Louis the Pious's librarian, his copy of Justinus found its way into the library of the Carolingian court where it became the exemplar for a number of manuscripts, and thus the archetype for the transalpine branch of the text. The idiosyncratic readings found in the Fischer-Bagford fragments single them out from the rest of the transalpine group and show that the original manuscript from which they came cannot hold the central position in the textual tradition which the theory about Gerward requires. Other conclusions about the rediscovered leaf are less firmly established. It was probably (but not certainly) written in England and at some stage travelled to the continent (unless we imagine that the manuscript was broken up in England). When it went abroad is unknown. The Bloomington fragment of Ælfric's Grammar shows the itinerary possible for a manuscript from a purely English context during the period of the great collectors. Despite the possibility that the leaf remained in England throughout the early Middle Ages (and, perhaps, beyond), the period of Anglo-Saxon activity on the continent provides a plausible background for the Bagford fragment. Even though the theory about Gerward cannot be sustained, the context which it suggests remains, in my opinion, the most likely. 89

89 My thanks are due to Dr David Dumville for drawing the Bagford fragment to my attention and for subsequent discussions and guidance on the matter, to Professor Helmut Gneuss for his prompt response to my enquiry about Fischer's fragment, and to Professor Michael Reeve, Dr Michael Lapidge and Dr Rosamond McKitterick for their comments after kindly reading this paper in draft. To $n$. 13 should be added R. McKitterick, "The Diffusion of Insular Culture in Neustria between 690 and 8,0: the Implications of the Manuscript Evidence', in La Neustrie. Les pays au nord de la Loire de Dagobert a Charles le Chauve ed. H. H. Atsma (forthcoming).

\section{APPENDIX \\ THE TEXT OF JUSTINUS'S EPITOME XXIV.ii.6-10, XXIV.iii.4-8 FROM LONDON, BL HARLEY 5919 , fol. 10}

(Recto)

fraternae crudelitatis timebat it[aque] plus liber[i]s quam sibi timens quos matr[i]monio suo protecturam se [ar]bitra[b]a- 


\section{Julia Crick}

tur [m]ittit ex amicis suis di[one]m quo

$\mathrm{pe}$ [r]ducto in sanctissimum iouis templ 'um' ueterrimae macedonum religionis ptolemeus sumptis in manus altaribus contingens ipsa simulacra et puluinaria deorum inauditis ultimisque exsecrationibus adiurat. se sincera fide sororis matrimonium petere nuncup[atu]rumque se eam reginam neque in contumeliam eius se aliam uxorem aliose qu'am' filios eius liberum habiturum arsinoe et postquam et spe impleta est et metu soluta ipsa cum fratre conloquitur cuius uultus et blandi[entes] oculi cum f[i]dem non minorem qu[am ius]

(Verso)

cupiditate fraus struebatur praegressa igitur uirum diem festum urbi in aduentum eius indicit domos templa ceteraque omnia exornari iubet. aras utique hostiasque disponi. filios quoque suos lysimacum sedecim annos natum philippum triennio minorem utrumque forma insignem coronatos occurrere iubet quos ptolemeus ad celebrandam fraudem cupide et ultra modum uere adfectionis amplexus osculis diu fatigat ubi ad portam uentum [est] occupari arcem iubet pueros interfici qui cum ad matrem confug[i]ssent in gremio eius inter ipsa oscula trucidantur. proclaman[te arsinoe] quid tantum nefas aut [..... aut] post nuptias contraxis[sent pro] filiis saepe se percusso-90

90 There are two scribal marginal notes. Of that on the recto, only the following can be distinguished: '[ius iuran]du[m] ?mei [pron]us [ ] sororis'. On the verso 'ptholemeus filius sororis interficit ipsam post nuptias in exilium mittit'. 